\title{
Cellular Physiology

\section{NFKB is an Unexpected Major Mediator of Interleukin-15 Signaling in Cerebral Endothelia}

\author{
Kirsten P. Stone, Abba J. Kastin and Weihong Pan \\ Blood-Brain Barrier Group, Pennington Biomedical Research Center, Baton Rouge
}

\section{Key Words}

$\mathrm{IL}-15 \cdot \mathrm{NF} \mathrm{KB} \cdot$ Cytokine receptors $\cdot \mathrm{BBB} \cdot$ Endothelial cells $\cdot$ TNF

\begin{abstract}
Interleukin (IL)-15 and its receptors are induced by tumor necrosis factor $\alpha$ (TNF) in the cerebral endothelial cells composing the blood-brain barrier, but it is not yet clear how IL-15 modulates endothelial function. Contrary to the known induction of JAK/ STAT3 signaling, here we found that nuclear factor (NF)- $\mathrm{KB}$ is mainly responsible for IL-15 actions on primary brain microvessel endothelial cells and cerebral endothelial cell lines. IL-15-induced transactivation of an $\mathrm{NF} \kappa \mathrm{B}$ luciferase reporter resulted in phosphorylation and degradation of the inhibitory subunit $l_{\kappa} B$ that was followed by phosphorylation and nuclear translocation of the p65 subunit of NFKB. An IKB kinase inhibitor Bay 11-7082 only partially inhibited IL-15-induced NFKB luciferase activity. The effect of IL-15 was mediated by its specific receptor IL-15R $\alpha$, since endothelia from IL-15R $\alpha$ knockout mice showed delayed nuclear translocation of p65, whereas those from knockout mice lacking a co-receptor IL-2R $\gamma$ did not show such changes. At the mRNA level, IL-15 and TNF showed similar effects in decreasing the tight
\end{abstract}

\section{KARGER}

Fax +4161306 1234

E-Mail karger@karger.ch

www.karger.com
(C) 2011 S. Karger AG, Basel

$1015-8987 / 11 / 0281-0115 \$ 38.00 / 0$

Accessible online at: www.karger.com/cpb junction protein claudin-2 and increasing the p65 subunit of $\mathrm{NF} \kappa \mathrm{B}$ but exerted different regulation on caveolin-1 and vimentin. Taken together, NFKB is a major signal transducer by which IL-15 affects cellular permeability, endocytosis, and intracellular trafficking at the level of the blood-brain barrier.

Copyright @ 2011 S. Karger AG, Basel

\section{Introduction}

Interleukin (IL)-15 is a ubiquitously expressed $14 \mathrm{kD}$ cytokine. It binds to its unique receptor IL- $15 \mathrm{R} \alpha$ as well as two co-receptors IL-2R $\beta$ (also termed IL$15 \mathrm{R} \beta$ ) and IL-2R $\gamma$ common chain. This heterotrimeric receptor complex is the high affinity form that activates Janus kinase (JAK) and Signal Transducer and Activator for Transcription (STAT) proteins [1-6]. In most cells the actions of IL-15 are mediated through the JAK/STAT pathway; however, little is known about IL-15-activated signaling in the microvascular endothelial cells that compose the blood-brain barrier (BBB).

Blood IL-15 levels are low in the resting state but increase after inflammatory and autoimmune challenges.

Kirsten P. Stone, Ph.D.

Blood-Brain Barrier Group, Pennington Biomedical Research Center 6400 Perkins Road, Baton Rouge, LA 70808 (USA)

Tel. +1-225-763-2718, Fax +1-225-763-0261

E-Mail kirsten.stone@pbrc.edu 
In endothelia of mouse cerebral microvessels and cultured rat brain endothelial (RBE)-4 endothelial cells, tumor necrosis factor $\alpha$ (TNF) stimulates both IL-15 and IL-15 receptor expression [7]. Similarly, the mRNA of all three IL-15 receptor subunits (IL-15R $\alpha$, IL-2R $\beta$, IL-2R $\gamma$ ) in both cerebral microvessels and CNS parenchyma can be increased by lipopolysaccharide (LPS), a prototypic inflammatory stimulus that activates TNF and other proinflammatory cytokines, as well as by experimental autoimmune encephalomyelopathy (EAE) $[8,9]$. In mice with EAE, IL-15 treatment provides neuroprotection and reduces behavioral deficits. Thus, we further hypothesize that IL-15 signaling in endothelial cells exerts cytoprotective effects against inflammation and impaired function of the BBB.

The master regulator of gene expression in inflammation is nuclear factor $\kappa \mathrm{B}(\mathrm{NF} \kappa \mathrm{B} / \mathrm{Rel})$. There are five members of the Rel family that can homo- and/ or heterodimerize with each other: p65/RelA, RelB, c-Rel, p50, and p52. Dimerization and nuclear translocation are tightly controlled by a family of inhibitory molecules (IKB) that keep NFKB in the cytoplasm [10]. TNF induces NFKB through a signaling cascade that includes binding to the TNF receptor (TNFR), binding of TNFR associated factor (TRAF)-2, activation of I $\mathrm{B}$ kinase (IKK), phosphorylation and proteasomal degradation of $\mathrm{I} \kappa \mathrm{B}$, dimerization and nuclear translocation of $\mathrm{NF \kappa B}$, and activation of gene expression by binding to cognate DNA binding sites $[11,12]$.

Thus, there are at least two potential models of TNF/IL-15 interactions within cerebral endothelia: (a) signaling crosstalk of TNF-induced NFKB and IL-15activated STAT3 and STAT5, as shown with a few other classes of receptors [13], or (b) convergence or antagonism of TNF and IL-15 signaling at NFKB. Both novel hypotheses could illustrate important principles in endothelial cell biology.

\section{Materials und Methods}

\section{Cells}

RBE4 cells of rat brain microvessel endothelial cell origin and hCMEC/D3 cells of human brain microvessel cell origin were both kindly provided by Dr. Pierre-Olivier Couraud (Institut Cochin, Paris, France). The cells were plated onto plates coated with collagen $(50 \mu \mathrm{g} / \mathrm{ml})$. RBE4 cells were cultured in $\alpha \mathrm{MEM} /$ Ham's F10 (1:1; Invitrogen, Carlsbad, CA) supplemented with $10 \%$ FBS (heat-inactivated; Invitrogen), $\beta F G F(1 \mathrm{ng} / \mathrm{ml}$ Invitrogen), and G418 (30 $\mu \mathrm{g} / \mathrm{ml}$; Invitrogen). hCMEC/D3 cells were cultured in EBM-2 media (Lonza, Basel, Switzerland) containing all provided supplements but without heparin.
Primary mouse brain microvessel endothelial cells (PBMEC) were isolated from brain cortices of wild-type or IL-15 receptor knockout (KO) mice following an approved Institutional Animal Care and Use protocol as previously described [14]. This includes 4- 6 week old, IL-15R $\alpha \mathrm{KO}$ and matching B6129SF2/J controls, and IL-2R $\gamma$ KO and matching B6 controls, all from Jackson Laboratories (Bar Harbor, ME).

\section{Transfection experiments}

RBE4 cells were plated onto a 48-well plate. Twenty-four $\mathrm{h}$ later, the STAT3 luciferase reporter $(0.1 \mu \mathrm{g} / \mathrm{well}$; kindly provided by Dr. Charles Rosenblum, Merck Research Laboratories, Rahway, NJ), the STAT5 luciferase reporter $(0.1 \mu \mathrm{g} /$ well; kindly provided by Dr. Charles V. Clevenger, Northwestern University, Chicago, IL), or the NFKB luciferase reporter $(0.1 \mu \mathrm{g} /$ well; Agilent Technologies, Santa Clara, CA) combined with a Renilla luciferase (10ng/well; Promega, Madison, WI) as an internal reference plasmid were transfected into $95 \%$ confluent cells by use of lipofectamine 2000 according to the manufacturer's instructions (Invitrogen). Transfection of RBE4 cells with GFP plasmids in similar concentrations showed that about $80-90 \%$ of cells were transfected. Twenty-four $\mathrm{h}$ after transfection and $12 \mathrm{~h}$ of serum-starvation, the cells were treated for $6 \mathrm{~h}$ with either IL-15 (Peprotech, Rocky Hill, NJ) or TNF $(5 \mathrm{ng} / \mathrm{ml})$, or a combination of both as indicated. To test the role of IKK, p38 mitogen-activated protein kinase (MAPK), and Akt on TNF and IL-15-induced NFkB transactivation, we used the inhibitors Bay 11-7082 (Bay; $10 \mu \mathrm{M}$; EMD Chemicals, Gibbstown, NJ) and SB203580 (30 $\mu$ M; Santa Cruz, Santa Cruz, $\mathrm{CA})$. Cells transfected with the NFKB luciferase reporter were treated for $6 \mathrm{~h}$ along with cytokines, and compared with a DMSO vehicle control studied concomitantly. Luminescence was detected by the Dual luciferase assay (Promega) according to the manufacturer's instructions. STAT3, STAT5, and NFאB luciferase activities were normalized by Renilla control luciferase activity. All groups contained triplicated wells, and each result was at least duplicated.

\section{Immunocytochemistry and Western blot analysis}

hCMEC/D3 and PBMEC cells were plated onto 8-well chambered Permanox slides (Thermo Fisher Scientific, Pittsburgh, PA) for immunocytochemistry and confluent cells then were incubated for 5,15 , or 30 min with human IL-15 $(5 \mathrm{ng} / \mathrm{ml}$; Peprotech). For immunocytochemistry, cells were fixed with $4 \%$ paraformaldehyde and then washed with phosphatebuffered saline (PBS), permeabilized for $30 \mathrm{~min}$ in $\mathrm{PBS} / 0.1 \%$ Triton $\mathrm{X}-100$, and blocked for $1 \mathrm{~h}$ in $10 \%$ normal donkey serum in PBS. Fixed cells were incubated overnight at $4{ }^{\circ} \mathrm{C}$ with mouse anti p65 (1:50; sc-8008; Santa Cruz) diluted in PBS/0.1\% Triton $\mathrm{X}-100 / 1 \%$ BSA. Then cells were washed three times with PBS for $5 \mathrm{~min}$ and incubated with Alexa488-conjugated anti-mouse secondary antibody (1:1000; Invitrogen) for $1 \mathrm{~h}$. After a thorough wash, slides were mounted with Vectashield mounting media containing DAPI (Vector Laboratories, Burlingame, CA). Immunofluorescence was captured on either an Olympus FV1000 inverted laser scanning microscope or a Zeiss Axioplan 2 fluorescence microscope connected to a Photometrics CoolSnap HQ CCD camera. 
For western blot analysis, hCMEC/D3 cells were plated onto 6-well plates. For control, one well was pretreated for $1 \mathrm{~h}$ with mouse anti IL-15 antibody (1:100; sc-8437; Santa Cruz), and other wells were treated with either human TNF $(5 \mathrm{ng} / \mathrm{ml}$; Peprotech) or IL-15 for 5 and 15 min. Similar experiments were performed in the presence of goat anti-TNF $\alpha$ antibody (1:100; sc-1351; Santa Cruz) in all wells. Cells were lysed with Cellytic (Sigma) and protein concentration was measured by the BCA method (Pierce). Lysates were electrophoresed on an SDS gel and transfered onto a nitrocellulose membrane. After being blocked with PBS-T/5\% milk, membranes were incubated with rabbit anti-pp65 (1:2000; ab31472; Abcam; Cambridge, UK), mouse anti-pIкB (\#9246), rabbit anti-pSTAT3 (\#9131), or rabbit anti-pSTAT5 (\#9359) antibodies (1:2000, all from Cell Signaling, Danvers, MA) overnight at $4^{\circ} \mathrm{C}$. After being washed, membranes were incubated with either anti-mouse HRP or anti-rabbit HRP (1:5000; Perkin Elmer, Boston, MA), and proteins were visualized by use of ECL substrate (Amersham). Then, membranes were stripped with Restore stripping buffer (Pierce) and incubated with either mouse anti-p65 (1:500; sc-8008, Santa Cruz), rabbit anti-IкB (1:2000; \#9242, Cell signaling), rabbit anti-STAT3 (1:1000; 06-596, Millipore), or rabbit anti-STAT5 antibodies (1:1000; sc-835, Santa Cruz) overnight at $4^{\circ} \mathrm{C}$. After additional

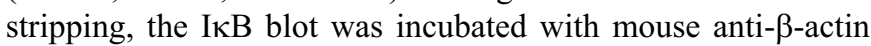
antibody (1:10000; A5441, Sigma, St. Louis, MO). Membranes were washed, incubated with secondary antibodies, and proteins were visualized as described above.

\section{$q P C R$}

hCMEC/D3 cells (passage \# 31-33) were plated onto 6 -well plates and incubated for $6 \mathrm{~h}$ with either human TNF $(5 \mathrm{ng} / \mathrm{ml})$ or human IL-15 (5 ng/ml). Then, mRNA was isolated by use of the ChargeSwitch kit according to the manufacturer's instructions (Invitrogen). mRNA was reverse transcribed with a Superscript RT kit with Oligo dT primers according to the manufacturer's instructions. cDNA concentrations were measured and $50 \mathrm{ng}$ cDNA was used together with genespecific primers (Table 1) and SYBR Green PCR Master Mix (Applied Biosystems, Carlsbad, CA) for qPCR on an ABI7900T. Induction of gene expression was determined by the $\Delta \Delta \mathrm{CT}$ method.

\section{Statistical Analysis}

Means were presented with their standard errors. Oneway ANOVA was performed to determine overall difference among groups, followed by Tukey's post-hoc test where appropriate.

\section{Results}

\section{IL-15 is a robust inducer of $N F \kappa B$ activation}

It is usually thought that IL-15 signals through STAT3 and STAT5 whereas TNF activates NF $\mathrm{B}$ as well as many other pathways. We tested the activation by IL-15 of both a STAT3 and a STAT5 luciferase reporter in RBE4 cells. STAT3 luciferase reporter induction by

IL-15 Activates NFкB Target Genes in BBB Cells

\begin{tabular}{|c|c|c|}
\hline $\begin{array}{l}\text { Gene } \\
\text { Gene bank } \\
\text { accession \# }\end{array}$ & Primer sequence $5^{\prime} \ldots 3^{\prime}$ & Amplicon size \\
\hline $\begin{array}{l}\text { Claudin-2 } \\
\text { NM } 020384\end{array}$ & $\begin{array}{ll}\text { F: } & \text { CTCCCTGGCCTGCATTATCTC } \\
\text { R: } & \text { CAGTGGTGAGTAGAAGTCCCG }\end{array}$ & $180 \mathrm{bp}$ \\
\hline Vimentin & F: CCTTGAACGCAAAGTGGAATC & $106 \mathrm{hn}$ \\
\hline NM_003380 & R: GACATGCTGTTCCTGAATCTGAG & \\
\hline Occludin & F: TCAAACCGAATCATTATGCACCA & $190 \mathrm{bp}$ \\
\hline NM_002538 & R: AGATGGCAATGCACATCACAA & $1900 \mathrm{p}$ \\
\hline $\mathrm{ZO}-\overline{2}$ & F: TCCAATCAAAACGCACAAGCC & $125 \mathrm{bp}$ \\
\hline AF_177533 & R: TCGGCATCACTGCCATAACTT & $1250 \mathrm{p}$ \\
\hline Caveolin-1 & F: ACATCTCTACACCGTTCCCAT & $205 \mathrm{bp}$ \\
\hline NM_001753 & R: TGTGTGTCCCTTCTGGTTCTG & \\
\hline TNFR1 & F: CCTGCCAGGAGAAACAGAACAC & 3561 \\
\hline NC_001065 & R: GGGACTGAAGCTTGGGTTTGG & \\
\hline$T N \overline{F R} 2$ & F : GCCCCACCAGATCTGTAACGTG & $366 \mathrm{bn}$ \\
\hline NM_001066 & R: TGAGGCACCTTGGCTTCTCTC & \\
\hline p65 & F: CTGATGTGCACCGACAAGTGG & $353 \mathrm{bp}$ \\
\hline NM_001145138 & R: GTTGAT GGTGCTCAGGGATGAC & \\
\hline$T R \overline{A F} 2$ & F: AACATTGTCTGCGTCCTGAACC & \\
\hline NM_021138 & R: CGTTCAGGTAGATACGCAGACACA & \\
\hline
\end{tabular}

Table 1. Primers used for quantitative PCR

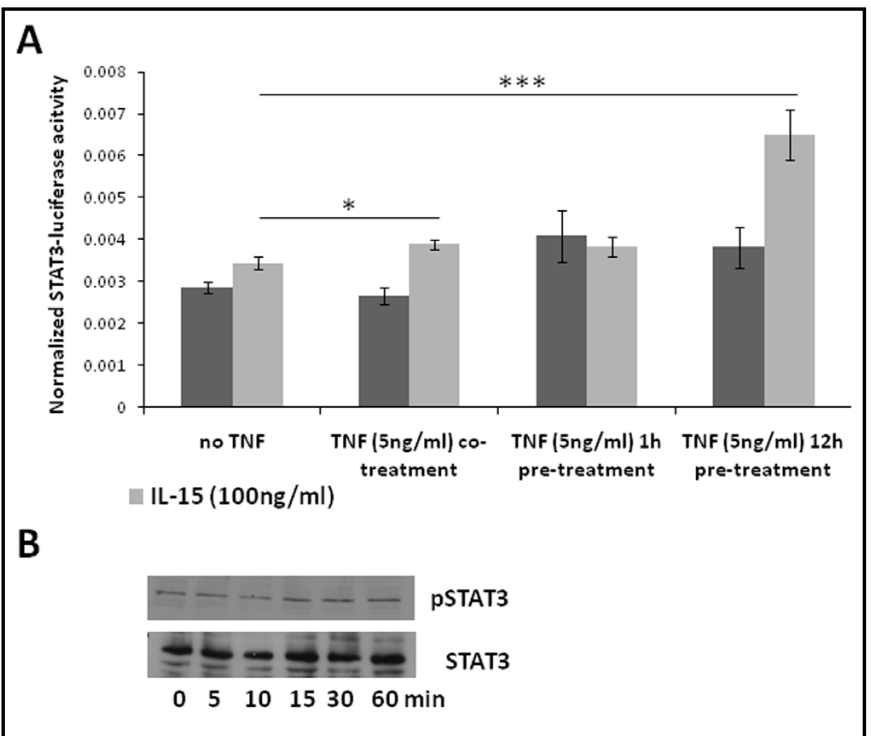

Fig. 1. TNF affects IL-15-induced STAT3 activation. (A) RBE4 cells transfected with a STAT3 luciferase reporter were treated with IL-15 (100 ng/ml; light bars) in the presence and absence of TNF as indicated (dark bars). Co-treatment significantly increased and pretreatment with TNF for $12 \mathrm{~h}$ doubled IL-15induced reporter activity $(* \mathrm{p}<0.05, * * * \mathrm{p}<0.005)$. The graph is representative of three independent experiments, $n=3 /$ data point. (B) hCMEC/D3 cells were treated with IL-15 (100ng/ml) for the indicated times and extracts were exposed to western blot analysis. Endogenous STAT3 was not phosphorylated. Similar results were obtained with RBE4 cells. Results shown are representative of each of two independent experiments with hCMEC/D3 and RBE4 cells.

IL-15 (100 ng/ml) was not significant (Fig. 1A). Similarly, endogenous phosphorylation of STAT3 was not induced by IL- 15 beyond the basal state in another brain microvessel endothelial cell line, the hCMEC/D3 cells (Fig. 1B). To test the hypothesis that TNF and IL-15 interact 
Fig. 2. IL-15 activates STAT5. (A) RBE4 cells transfected with a STAT5 luciferase reporter were treated with IL-15 (100 ng/ml; light bars) in the presence and absence of TNF as indicated (dark bars). Whereas IL-15 induced STAT5 luciferase activity $(* \mathrm{p}<0.05, * * * \mathrm{p}<0.005)$, TNF had no effect. The graph is representative of two independent experiments, $n=3 /$ data point. (B) hCMEC/D3 cells were treated with IL-15 (100 ng/ml) for the indicated times and extracts were exposed to western blot analysis. Endogenous STAT5 was phosphorylated within 5 min. Similar results were obtained with RBE4 cells. Results shown are representative of each two independent experiments with hCMEC/D3 and RBE4 cells.

with each other in STAT3 activation, we performed STAT3 luciferase reporter assays in cells receiving TNF by pretreatment or co-treatment with IL15. Whereas cotreatment of cells with TNF slightly but significantly increased IL-15-induced STAT3 luciferase reporter activity, pre-treatment for $12 \mathrm{~h}$ doubled it (Fig. 1A). However, combined treatment with TNF and IL-15 for $60 \mathrm{~min}$ did not increase STAT3 phosphorylation as seen in western blotting (data not shown). Nevertheless, IL-15 increased the STAT5 luciferase reporter 1.5 fold (Fig. 2A), whereas TNF had no effect on reporter activity. Endogenous STAT5 in hCMEC/D3 cells was phosphorylated within 5 min after IL-15 treatment and persisted for $15 \mathrm{~min}$ (Fig. 2B).

Unexpectedly, IL-15 alone was sufficient to induce NFKB transcriptional activation in RBE4 cells as shown by the NFKB luciferase reporter assay. TNF was also effective in inducing NFKB transcriptional activation. We used $5 \mathrm{ng} / \mathrm{ml}$ of TNF since higher doses are known to impair cellular ATP production and cause cytotoxicity in RBE4 cells [15]. However, the combination of TNF and IL-15 did not induce a further increase of NFкB luciferase activity (Fig. 3A). Dose-response studies showed that $1 \mathrm{ng} / \mathrm{ml}$ of IL-15 exerted maximal effect, and there was no additional increase in the group treated with $5-100 \mathrm{ng} / \mathrm{ml}$ of IL-15 (Fig. 3B). Since the NFKB luciferase reporter we used contains only five copies of the $\kappa \mathrm{B}$ DNA binding site, IL-15 must activate signaling pathways that result in binding of NFKB to its DNA binding site. Therefore, we next tested whether IL-15 induces nuclear translocation of $\mathrm{p} 65$, which showed cytoplasmic distribution in hCMEC/D3 cells pretreated with a neutralizing anti-IL-15 antibody. Treatment with IL-15 $(5 \mathrm{ng} / \mathrm{ml})$, however, resulted in nuclear translocation of p65 within $15 \mathrm{~min}$. This persisted at $30 \mathrm{~min}$ after treatment (Fig. 4A).
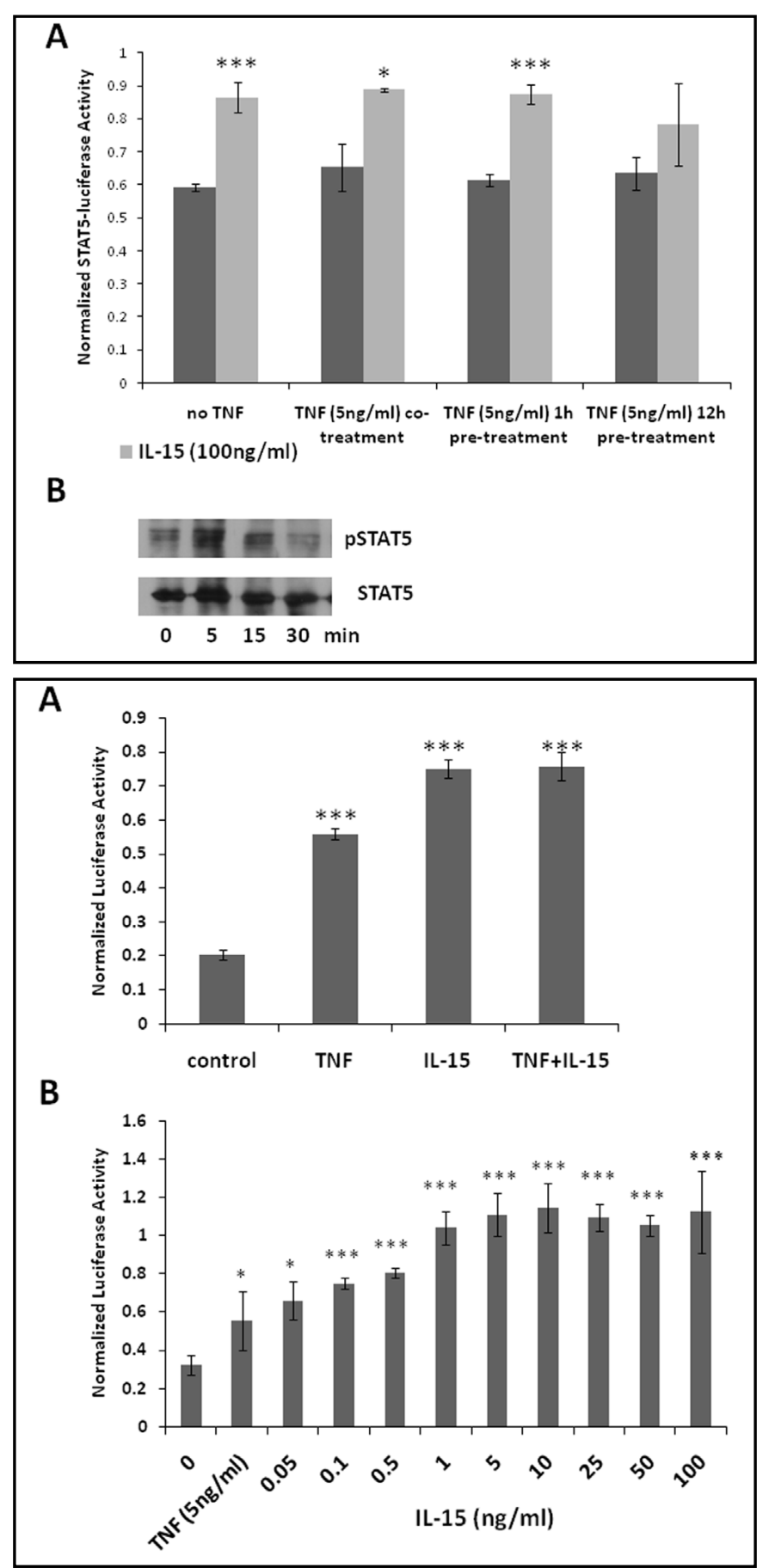

Fig. 3. In RBE4 cells, a low concentration of IL-15 is sufficient for full activation of NFKB luciferase reporter in the absence of TNF. The NFאB luciferase reporter contains 5 copies of the $\kappa B$ DNA binding element (TGG GGA CTT TCC GC). (A) Cells were treated for $6 \mathrm{~h}$ with either TNF $(5 \mathrm{ng} / \mathrm{ml})$ or IL-15 $(100 \mathrm{ng} / \mathrm{ml})$, or a combination of both. The results show that IL-15 activates the reporter $(* * * p<0.005$ compared with control). (B) Cells were treated for $6 \mathrm{~h}$ with IL-15 only in concentrations as indicated or with TNF $(5 \mathrm{ng} / \mathrm{ml})$ for comparison. The results show maximal induction with $1 \mathrm{ng} / \mathrm{ml} \mathrm{IL}-15(* \mathrm{p}<0.05, * * * \mathrm{p}<0.005$ compared with control). Graphs are representative of three independent experiments, each with $n=3 /$ data point. Data are presented as mean \pm S.E.

Stone/Kastin/Pan 
Fig. 4. IL-15 induces phosphorylation and nuclear translocation of p65 within $15 \mathrm{~min}$ after treatment. hCMEC/D3 cells were treated with either IL-15 $(5 \mathrm{ng} / \mathrm{ml})$ or TNF $(5 \mathrm{ng} / \mathrm{ml})$ for the indicated time. As control, cells were treated with neutralizing TNF (anti TNF $\alpha$ ) or IL-15 antibodies (anti IL-15) as indicated. (A) Cells were fixed and stained with an anti-p65 antibody. Bar: $50 \mu \mathrm{m}$. Western blot analysis of cell extracts showed (B) phosphorylation of p65 after 15 min with IL-15 and TNF in the absence of neutralizing TNF antibody, but only for IL-15 and not TNF in the presence of neutralizing TNF antibody, and (C) phosphorylation and partial degradation of IкB. Data shown are representative of two independent experiments.

Phosphorylation of p65 typically precedes nuclear translocation. In hCMEC/D3 cells, IL-15 induced phosphorylation of p 65 within $15 \mathrm{~min}$, as did TNF (Fig.4B, upper panel). TNF-induced but not IL-15-induced phosphorylation of $\mathrm{p} 65$ was abolished in the presence of a TNF neutralizing antibody, indicating the direct activation of p65 by IL-15 (Fig. 4B, lower panel).

TNF-induced activation of NFKB is preceded by phosphorylation and degradation of $\mathrm{I} \kappa \mathrm{B}$. To determine whether IL-15 uses a pathway similar to TNF for activation of $\mathrm{NF \kappa B}$, we next determined expression of phosphorylated I $\mathrm{KB}$ in hCMEC/D3 extracts. As shown in Fig. 4C, both IL-15 and TNF induced phosphorylation and partial degradation of I $\mathrm{KB}$ within 5 and $15 \mathrm{~min}$, respectively.

IKB is mainly phosphorylated by IKK but p38 MAPK and Akt also may play a role in IL-15 mediated activation of NFKB. Therefore, we performed transactivation assays in the presence of inhibitors. Treatment with the IKK inhibitor Bay increased basal transcriptional activity by $45 \%$. As expected, Bay significantly inhibited TNF-induced NFKB activation by $74 \%$, whereas IL-15-induced NFKB activation was only inhibited by $25 \%$ (Fig. 5). At the concentration used, SB203580 inhibited both p38 MAPK and Akt. Inhibitor treatment increased basal transcriptional activity by $40 \%$. Whereas SB203580 had no significant effect on TNF-induced NF $\kappa B$ activation $(-9 \%)$, it inhibited IL-15-induced NFKB activation by $48 \%$. Taken together, these results indicate that IL-15 uses pathways downstream of IкB phosphorylation similar to TNF, whereas upstream pathways may differ.

\section{Role of the specific receptor $I L-15 R \alpha$}

IL-15 activates signaling through its receptors IL-15R $\alpha$, IL-2R $\beta$, and IL-2R $\gamma$, with IL-15R $\alpha$ being the high affinity receptor, and IL-2R $\beta / \mathrm{IL}-2 \mathrm{R} \gamma$ acting as low

IL-15 Activates NFkB Target Genes in BBB Cells
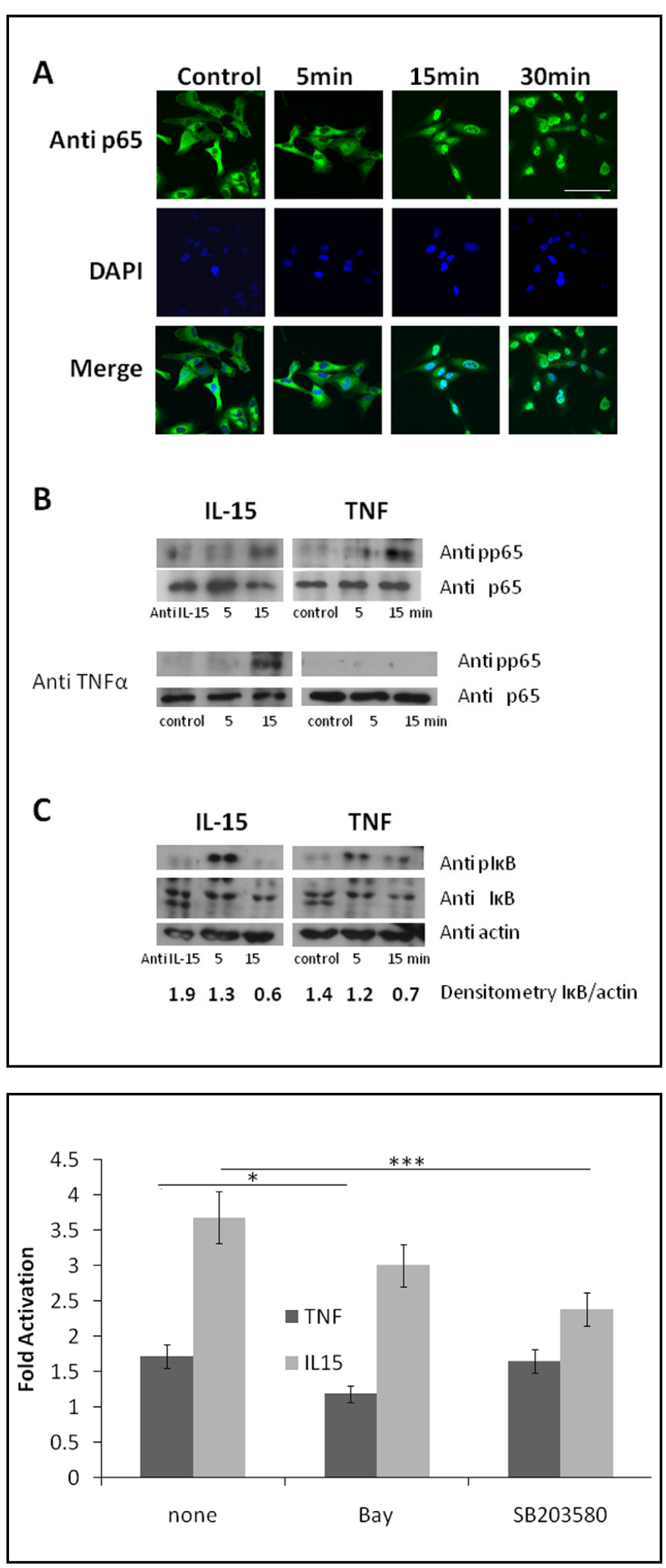

Fig. 5. IL-15-mediated activation of NFאB may involve p38MAPK/Akt pathways. RBE4 cells expressing an NFкB luciferase reporter were pretreated for $1 \mathrm{~h}$ with either Bay 11-7082 (Bay) or SB203580. Cells were then treated with either IL-15 $(5 \mathrm{ng} / \mathrm{ml})$ or TNF $(5 \mathrm{ng} / \mathrm{ml})$ for $6 \mathrm{~h}$ in the presence or absence of inhibitors. Data are presented as fold-induction of respective controls. ${ }^{*} \mathrm{p}<0.05, * * * \mathrm{p}<0.005$.

Cell Physiol Biochem 2011;28:115-124 
Fig. 6. IL-15-mediated nuclear translocation of p65 is delayed in the absence of IL-15R $\alpha$. Primary brain microvessel endothelial cells isolated from mice with genetic knockout of either IL-15R $\alpha$ (A) or IL-2R $\gamma$ (B; upper panels) and their age-matched controls (lower panels) were treated with IL-15 (5 ng/ml) for the indicated time, and then fixed and stained with an anti p65 antibody. Whereas p65 in cells from control and IL-2R $\gamma$ KO mice translocated into the nucleus within $15 \mathrm{~min}$, translocation was delayed in cells from IL-15R $\alpha \mathrm{KO}$ mice. Bar: $5 \mu \mathrm{m}$.

affinity receptors. Most signaling requires the IL-2R $\beta /$ IL-2R $\gamma$ dimer. To explore which receptor units are required for activation of $\mathrm{NF \kappa B}$, we used primary microvessel endothelial cells from mice genetically modified to lack either IL-15R $\alpha$ or IL-2R $\gamma$ and their age-matched controls. Treatment with TNF and IL-15 for the indicated time confirmed that p65 translocates into the nucleus of endothelial cells from wild-type mice within 15 minutes, similar to that seen in hCMEC/D3 cells (Figs. 6A and B). Whereas p65 was found in nuclei of cells lacking IL-2R $\gamma$ within 15 minutes (Fig. 6B), p65 translocation took 30 minutes in cells lacking IL-15R $\alpha$ (Fig. 6A). These results indicate that IL-15R $\alpha$ plays a role in IL-15-mediated $\mathrm{NF} \kappa \mathrm{B}$ activation.

\section{Effects of IL-15-induced $N F \kappa B$ activation on} endothelial functions

To determine how IL-15 modulates endothelial functions, hCMEC/D3 cells were subjected to IL-15 treatment for $6 \mathrm{~h}$ and the gene expression profile related to NFאB activation was analyzed by qPCR. Besides the PBS vehicle control, an additional group of cells received TNF treatment for comparison with IL-15. Since TNF increases the expression of IL-15 and IL-15R $\alpha$ which may in turn regulate genes required for endothelial TNF signaling, we first measured expression of the $p 65$ subunit of NFкB, TNFR1, TNFR2, and the TNFR associated factor 2 (TRAF2) known to also bind IL-15R $\alpha$ [16]. Among these genes, p65 and TNFR2 promoters have

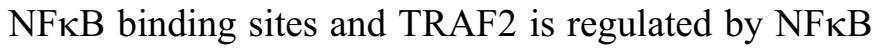
[17]. We found that both TNF and IL-15 up-regulate $p 65$ expression (Fig. 7, upper panel). Both TNF and IL-15 decreased TNFR 1 and increased TNFR 2 expression, but the effects were not significant. Whereas TNF had no effect, IL-15 tended to increase TRAF2 expression.

Next, we determined the levels of expression of a set of genes related to endothelial functions, including maintenance of BBB properties. This list includes junctionassociated proteins and transport proteins. Among them,

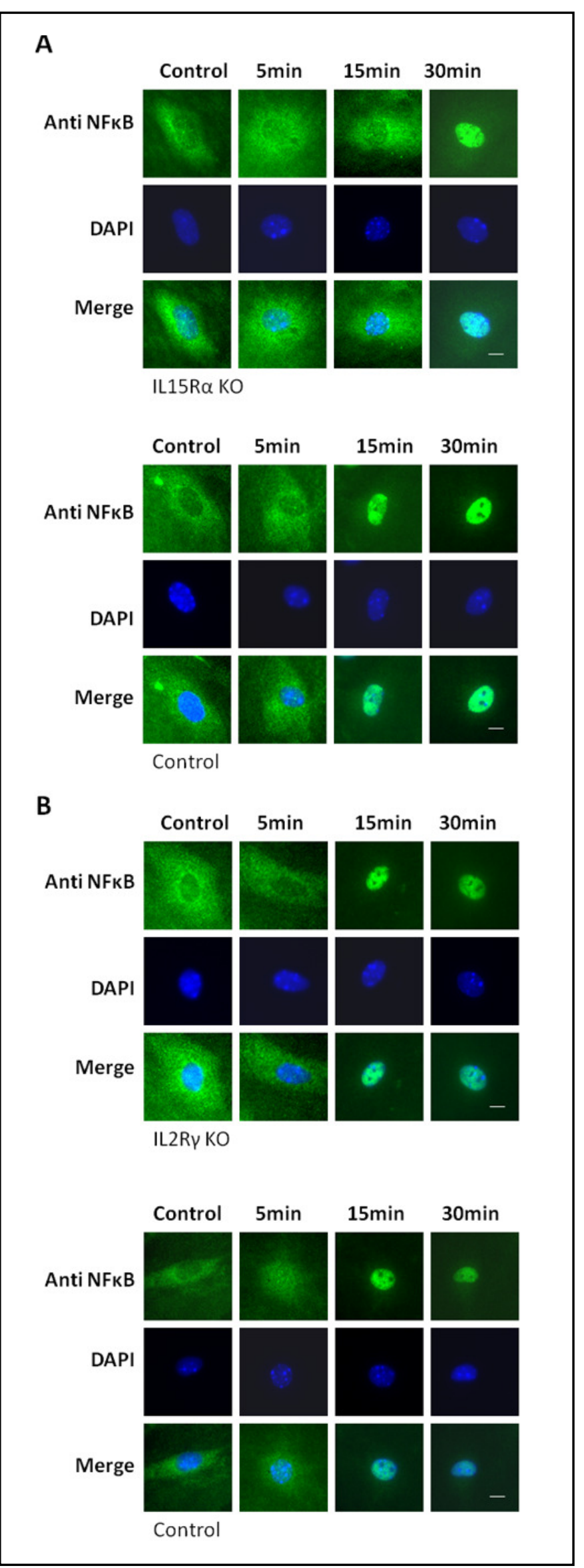

Stone/Kastin/Pan 


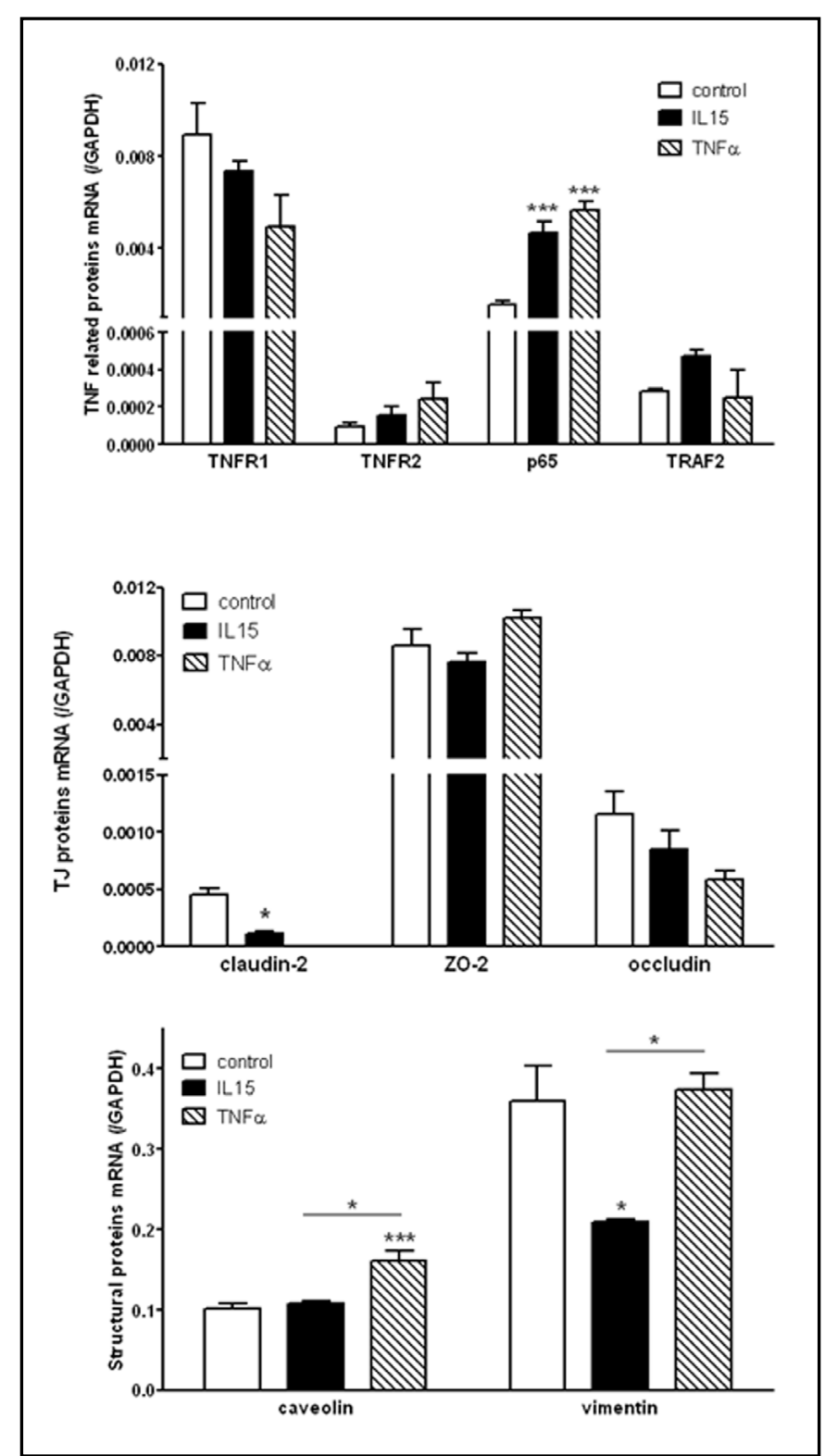

Fig. 7. IL-15 selectively regulates expression of NFKB target genes. hCMEC/D3 cells were treated for $6 \mathrm{~h}$ with either IL-15 $(5 \mathrm{ng} / \mathrm{ml})$ or TNF $(5 \mathrm{ng} / \mathrm{ml})$. qPCR was used to compare the effect of IL-15 and TNF on expression of TNF-related (upper panel), tight junction (TJ; center panel), and structural proteins (lower panel). Claudin-2, p65, TNFR2, TRAF2, caveolin, and vimentin are potential NFKB target genes, whereas $Z O-2$ and occludin are not. Graphs are representative of two independent experiments, each with $\mathrm{n}=3$ /data point. ${ }^{*} \mathrm{p}<0.05$, $* * * \mathrm{p}<0.005$.

caveolin [18], claudin-2 [19], and vimentin [20] expression is regulated by $\mathrm{NF} \kappa \mathrm{B}$, whereas occludin and zona occludin (ZO)-2 expression is not. We found that IL-15 significantly decreased and TNF abolished the expression of claudin-2, whereas neither significantly affected expression of occludin or ZO-2 (Fig. 7, center panel). However, expression of caveolin was only affected by

IL-15 Activates NFkB Target Genes in BBB Cells
TNF, whereas expression of vimentin was only affected by IL-15 (Fig. 7, lower panel).

Western blot analysis of p65, TRAF2, caveolin, and vimentin expression in hCMEC/D3 cells after 6,12 , and $24 \mathrm{~h}$ treatment with either IL-15 or TNF did not show significant changes in protein expression (data not shown). Taken together, these results indicate that IL-15 plays a role in transcriptional control of p65 and in selective regulation of $\mathrm{NF} \kappa \mathrm{B}$ target genes.

\section{Discussion}

We show here that IL-15 activates an NFкB luciferase reporter, and regulates the transcription of $\mathrm{p} 65$ as well as of junction-associated and cytoskeletal proteins in brain microvessel endothelial cells. IL-15 is a powerful antagonist of TNF's pro-apoptotic functions since IL-15 deflects TRAF2 from the TNF receptor toward the IL-15R $\alpha$ chain [21]. By contrast, we showed that IL-15 induced NFKB activation and nuclear translocation. The results demonstrate that IL-15 induces NFkB target genes both similarly and differently from TNF.

Our results indicate that IL-15R $\alpha$ plays a role in IL-15-induced NFKB activation. IL-15 recruits TRAF2 to IL-15R $\alpha$ [21], but IL-2R $\beta$ and IL-2R $\gamma$ are not involved. Variations in the strengths of the interaction between TRAF2 and IL-15R $\alpha$ have been shown in two different melanoma cell lines [16]. This may explain why in some cells but not others IL-15 can induce NFкB [22]. There are multiple pathways that can lead to phosphorylation of I $\mathrm{B}$. In contrast to TNF, IL-15-induced activation of NFKB was only partially inhibited by the IKK inhibitor BAY, indicating a role of alternative kinases for IL-15mediated phosphorylation of I $\kappa B$.

NFKB can also be activated through p38 MAPK and Akt-mediated pathways $[23,24]$. IL-1 $\beta$ requires Akt to induce NFкB in an IKK- and p38 MAPK-dependent manner [25]. IL-15 could potentially induce p 38 MAPK and Akt through scaffolding proteins interacting with either IL-2R $\beta$ or STAT5 $[26,27]$. We found that an inhibitor of both $\mathrm{p} 38$ MAPK and Akt partially inhibits IL-15-induced $\mathrm{NF} \kappa \mathrm{B}$ transactivation, indicating a role of kinases other than IKK in I $\mathrm{K} B$ phosphorylation. The activation of $\mathrm{p} 38$ MAPK and NFKB in cerebral endothelia by IL-15 is similar to that shown in stimulated microglia [28].

$\mathrm{NF} \kappa \mathrm{B}$ regulates the proinflammatory response in endothelial cells [29]. TNF activates NFKB mainly by TNFR2-mediated pathways, whereas TNF binding to TNFR 1 can induce apoptosis. IL-15 is known to protect 
various types of cells from TNF-induced apoptosis [3034]; this may involve activation of NFKB $[16,35]$. TNFR2 and TRAF2 play a role in diverting TNF actions from death-receptor mediated apoptosis to $\mathrm{NF} \kappa \mathrm{B}$ activation $[36,37]$. Our findings show that IL-15 increases the expression of $p 65$ and $T R A F 2$, which may be another mechanism contributing to its anti-apoptotic properties. Although IL-2 and IL-15 share common IL-2R $\beta / I L-2 R \gamma$ receptor units, this effect is specific for IL-15, as IL-2 does not activate NFKB in neutrophils [38].

The BBB is a unique structure composed by specialized endothelial cells joined by tight junctions, underlaid by a continuous basement membrane, and reinforced by other cellular components such as astrocytic endfeet, pericytes, and microglia [39, 40]. The BBB responds to inflammation with increased cytokine production, activation of transport proteins such as caveolin [41], increased permeability, and selective upregulation of cytokine transport $[42,43]$. NFKB plays a role in these changes, and this may be mediated by target gene products such as caveolin-1 [18] and the tight junction protein claudin-2 [44]. Beyond inflammatory signaling affecting tight junction proteins, $\mathrm{NF \kappa B}$ may also influence endothelial functions by regulating target gene products such as vimentin [20], an intracellular intermediate filament contributing to endothelial cell shape and implicated in formation of invadopodia [45, 46]. Thus, comparison of the effects of TNF and IL-15 on the target genes regulating $\mathrm{BBB}$ functions shows that the effects of NFKB activation may be cytokine-specific.

Since NFKB is a transcription factor shared by TNF and IL-15, we determined the target genes in cerebral endothelia that are potential targets of regulation by both cytokines. Among the genes tested, claudin-2, known to be regulated by NFKB, was decreased by both TNF and IL-15, but vimentin and caveolin were differentially regulated. This indicates that transcription factors other than $\mathrm{NF \kappa B}$ may play a more important role in the expression of these proteins. For example, the promoter of the caveolin gene contains both an NFKB and a STAT5 binding site, so that IL-15 might act through both transcription factors to regulate caveolin.

The expression profile of tight junction proteins in hCMEC/D3 cerebral endothelial cells differs from that in intestinal cells in response to IL-15. In our study, IL-15 had no effect on ZO-2 expression. In the human intestinal epithelial cell line T-84, IL-15 up-regulates ZO-2 independently of IL-2R $\beta$ but facilitates the functions of occludin and claudins by IL-2R $\beta$ [47]. We showed that TNF suppressed claudin-2 expression in cerebral

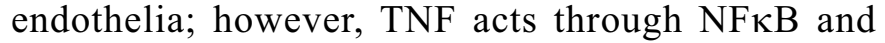
increases claudin-2 in HT-29/B6 human colon cells [44]. Nonetheless, the TNF-induced increase of caveolin [48] and decrease of occludin expression in endothelial cells [49] is consistent with our results. We chose the hCMEC/ D3 cell line as a model system since TNF activates NFKB in these cells and they express TNF receptors $[50,51]$. Overall, there is cell type specific regulation of junctional proteins.

Another novel finding is that IL-15 decreases vimentin expression. Vimentin is an intermediate filament important for the three-dimensional structure of endothelial cells. In astrocytes, vimentin also plays a role in vesicular trafficking [52]. During hypoxia, expression of vimentin increases in brain microvessel endothelial cells [53]. Similar to our results, TNF caused no change in vimentin expression in bovine cerebral microvessel endothelia [54]. Thus, IL-15 may act both as a mediator and an antagonist of TNF actions though it is produced in response to TNF.

An unusual finding is that TNF co-treatment with IL-15 increased activation of the STAT3 but not of the STAT5 luciferase reporter. Since TNF and IL-15 cotreatment did not induce STAT3 phosphorylation within minutes, the increase in STAT3 activation is probably indirect. The effect of TNF on IL-15-mediated activation of STAT3 is most pronounced after $12 \mathrm{~h}$ pretreatment, which may be explained by the inducing effect of TNF on IL-15 and IL-2R $\gamma$ expression in RBE4 cells [7]. This TNF-mediated increase in STAT3 activation may result in the regulation of genes important for functions of brain microvessel endothelial cells by IL-15.

Taken together, in brain microvessel endothelial cells IL-15 can induce both STAT5 and NFKB. Activation of $\mathrm{NF} \kappa \mathrm{B}$ appears to be more sensitive to low concentrations of IL-15 and TNF does not have cumulative or additional effects on STAT5 and NFKB activation by IL-15. By contrast, TNF affects IL-15-dependent STAT3 activation. These results indicate a complex but specific crosstalk between TNF- and IL-15-induced signaling in brain microvessel endothelial cells. Endothelial signaling is an integral part of the BBB response to cytokines, and it plays an essential role in modulation of CNS functions. Besides illustrating that $\mathrm{NF \kappa B}$ is an unexpected mediator for IL-15 signaling at the level of the BBB endothelia, we showed that IL-15 signaling modifies the actions of TNF. Since upregulation of the IL-15 system is a major inflammatory response of the BBB endothelia to TNF [7], IL-15 signaling appears to provide feedback control for TNF function. This indicates a dynamic regulation of BBB functions.

Stone/Kastin/Pan 


\section{Acknowledgements}

Funding support was provided by NIH (DK54880 to AJK and NS62291 to WP). hCMEC/D3 and RBE4 cells were provided by Dr. Pierre-Olivier Couraud (Institut
Cochin, INSERM, Paris, France). The STAT3 luciferase reporter was provided by Dr. Charles Rosenblum, Merck Research Laboratories, Rahway, NJ; the STAT5 luciferase reporter was provided by Dr. Charles V. Clevenger, Northwestern University, Chicago, IL.

\section{References}

1 Giri JG, Ahdieh M, Eisenman J, Shanebeck K, Grabstein K, Kumaki S, Namen A, Park LS, Cosman D, Anderson D: Utilization of the beta and gamma chains of the IL2 receptor by the novel cytokine IL-15. EMBO J 1994;13:2822-2830.

-2 Giri JG, Kumaki S, Ahdieh M, Friend DJ, Loomis A, Shanebeck K, DuBose R, Cosman D, Park LS, Anderson DM: Identification and cloning of a novel IL15 binding protein that is structurally related to the alpha chain of the IL-2 receptor. EMBO J 1995;14:3654-3663. Johnston JA, Bacon CM, Finbloom DS, Rees RC, Kaplan D, Shibuya K, Ortaldo JR, Gupta S, Chen YQ, Giri JD: Tyrosine phosphorylation and activation of STAT5, STAT3, and Janus kinases by interleukins 2 and 15. Proc Natl Acad Sci USA 1995;92:8705-8709.

-4 de Jong JL, Farner NL, Widmer MB, Giri JG, Sondel PM: Interaction of IL-15 with the shared IL-2 receptor beta and gamma c subunits. The IL-15/beta/gamma c receptor-ligand complex is less stable than the IL-2/beta/gamma c receptorligand complex. J Immunol 1996;156:1339-1348.

-5 Nielsen M, Nordahl M, Svejgaard A, Odum $\mathrm{N}$ : Interleukin 2 and 15 activate Stat3alpha in human $\mathrm{T}$ lymphocytes. Cytokine 1998;10:735-738.

6 de Totero D, Meazza R, Capaia M, Fabbi M, Azzarone B, Balleari E, Gobbi M, Cutrona G, Ferrarini M, Ferrini S: The opposite effects of IL-15 and IL-21 on CLL B cells correlate with differential activation of the JAK/STAT and ERK1/ 2 pathways. Blood 2008;111:517-524.

7 Pan W, Yu C, Hsuchou H, Khan RS, Kastin AJ: Cerebral microvascular IL15 is a novel mediator of TNF action. $\mathrm{J}$ Neurochem 2009;111:819-827.

-8 Pan W, Wu X, Kastin AJ, Zhang Y, Hsuchou H, Halberg H, Chatu F, Khan RS, Robert B, Kastin AJ: Potential protective role of IL15Ra during inflammation. $\mathrm{J}$ Mol Neurosci 2010;43:412-423.
Wu X, Pan W, He Y, Hsuchou H, Kastin AJ: Cerebral interleukin-15 shows upregulation and beneficial effects in experimental autoimmune encephalomyelitis. J Neuroimmunol 2010;223:65-72.

Sun SC, Ganchi PA, Beraud C, Ballard DW, Greene WC: Autoregulation of the NF-kappa B transactivator RelA (p65) by multiple cytoplasmic inhibitors containing ankyrin motifs. Proc Natl Acad Sci USA 1994;91:1346-1350. Dempsey PW, Doyle SE, He JQ, Cheng G: The signaling adaptors and pathways activated by TNF superfamily. Cytokine Growth Factor Rev 2003;14:193-209. Yu C, Argyropoulos G, Zhang Y, Kastin AJ, Hsuchou H, Pan W: Neuroinflammation activates $\mathrm{Mdrlb}$ efflux transport through NFkappaB: promoter analysis in BBB endothelia. Cell Physiol Biochem 2008;22:745-756.

Zhang Y, Wu X, He Y, Kastin AJ, Hsuchou $\mathrm{H}$, Rosenblum CI, Pan W: Melanocortin potentiates leptin-induced STAT3 signaling via MAPK pathway. J Neurochem 2009;110:390-399.

Stone KP, Kastin AJ, Hsuchou H, Yu C, Pan W: Rapid endocytosis of interleukin15 by cerebral endothelia. J Neurochem 2011;116:544-553.

Yu C, Kastin AJ, Ding Y, Pan W: Gamma glutamyl transpeptidase is a dynamic indicator of endothelial response to stroke. Exp Neurol 2007;203:116-122. Pereno R, Giron-Michel J, Gaggero A, Cazes E, Meazza R, Monetti M, Monaco E, Mishal Z, Jasmin C, Indiveri F, Ferrini S, Azzarone B: IL-15/IL-15Ralpha intracellular trafficking in human melanoma cells and signal transduction through the IL-15Ralpha. Oncogene 2000;19:5153-5162.

Wang CY, Mayo MW, Korneluk RG, Goeddel DV, Baldwin AS: NF-kappaB antiapoptosis: induction of TRAF1 and TRAF2 and c-IAP1 and c-IAP2 to suppress caspase- 8 activation. Science 1998;281:1680-1683.
$>18$ Tiruppathi C, Shimizu J, MiyawakiShimizu K, Vogel SM, Bair AM, Minshall RD, Predescu D, Malik AB: Role of NFkappaB-dependent caveolin-1 expression in the mechanism of increased endothelial permeability induced by lipopolysaccharide. J Biol Chem 2008;283:4210-4218.

19 Yamamoto T, Kojima T, Murata M, Takano K, Go M, Chiba H, Sawada N: IL-1beta regulates expression of $\mathrm{C} \times 32$, occludin, and claudin-2 of rat hepatocytes via distinct signal transduction pathways. Exp Cell Res 2004;299:427-441.

20 Lilienbaum A, Paulin D: Activation of the human vimentin gene by the Tax human T-cell leukemia virus. I. Mechanisms of regulation by the NFkappa B transcription factor. J Biol Chem 1993;268:2180-2188.

21 Pereno R, Gaggero A, Scudeletti M, Lanza L, Meazza R, Mishal Z, Jasmin C, Indiveri F, Ferrini S, Azzarone B: IL-15/ IL-15R alpha intracellular trafficking in human cells and protection from apoptosis. Ann N Y Acad Sci 1999;876:236-245.

22 Giron-Michel J, Caignard A, Fogli M, Brouty-Boye D, Briard D, van Dijk M, Meazza R, Ferrini S, Lebousse-Kerdiles C, Clay D, Bompais H, Chouaib S, Peault B, Azzarone B: Differential STAT3, STAT5, and NF-kappaB activation in human hematopoietic progenitors by endogenous interleukin-15: implications in the expression of functional molecules. Blood 2003;102:109-117.

23 Pilette C, Detry B, Guisset A, Gabriels J, Sibille Y: Induction of interleukin-10 expression through Fcalpha receptor in human monocytes and monocytederived dendritic cells: role of $\mathrm{p} 38$ MAPKinase. Immunol Cell Biol 2010;88:486-493.

24 Romashkova JA, Makarov SS: NFkappaB is a target of AKT in antiapoptotic PDGF signalling. Nature 1999;401:86-90. 
-25 Madrid LV, Mayo MW, Reuther JY, Baldwin AS: Akt stimulates the transactivation potential of the RelA/ p65 Subunit of NF-kappa B through utilization of the Ikappa B kinase and activation of the mitogen-activated protein kinase p38. J Biol Chem 2001;276:18934-18940.

-26 Nyga R, Pecquet C, Harir N, Gu H, Dhennin-Duthille I, Regnier A, GouilleuxGruart V, Lassoued K, Gouilleux F: Activated STAT5 proteins induce activation of the PI 3-kinase/Akt and Ras/MAPK pathways via the Gab2 scaffolding adapter. Biochem J 2005;390:359-366

$27 \mathrm{Gu}$ H, Maeda H, Moon JJ, Lord JD, Yoakim M, Nelson BH, Neel BG: New role for Shc in activation of the phosphatidylinositol 3-kinase/Akt pathway. Mol Cell Biol 2000;20:7109. 7120 .

28 Gomez-Nicola D, Valle-Argos B, NietoSampedro M: Blockade of IL-15 activity inhibits microglial activation through the NFkappaB, p38, and ERK1/2 pathways, reducing cytokine and chemokine release. Glia 2010;58:264-276.

29 Kempe S, Kestler H, Lasar A, Wirth T: NF-kappaB controls the global proinflammatory response in endothelial cells: evidence for the regulation of a pro-atherogenic program. Nucleic Acids Res 2005;33:5308-5319.

$>30$ Bulfone-Paus S, Ungureanu D, Pohl T, Lindner G, Paus R, Ruckert R, Krause H, Kunzendorf $\mathrm{U}$ : Interleukin-15 protects from lethal apoptosis in vivo. Nat Med 1997;3:1124-1128

31 Malamut G, El Machhour R, Montcuquet N, Martin-Lanneree S, Dusanter-Fourt I, Verkarre V, Mention JJ, Rahmi G, Kiyono H, Butz EA, Brousse N, Cellier C, Cerf-Bensussan N, Meresse B: IL-15 triggers an antiapoptotic pathway in human intraepithelial lymphocytes that is a potential new target in celiac diseaseassociated inflammation and lymphomagenesis. J Clin Invest $>42$ 2010;120:2131-2143.

$\$ 32$ Obermeier F, Hausmann M, Kellermeier S, Kiessling S, Strauch UG, Duitman E, Bulfone-Paus S, Herfarth H, Bock J, Dunger N, Stoeck M, Scholmerich J, Falk W, Rogler G: IL-15 protects intestinal epithelial cells. Eur J Immunol 2006;36:2691-2699.

-33 Hodge DL, Yang J, Buschman MD, Schaughency PM, Dang H, Bere W, Yang Y, Savan R, Subleski JJ, Yin XM, Loughran TP, Young HA: Interleukin-15 enhances proteasomal degradation of bid in normal lymphocytes: implications for large granular lymphocyte leukemias. Cancer Res 2009;69:3986-3994.
Huang Z, Ha GK, Petitto JM: IL-15 and IL-15R alpha gene deletion: effects on $T$ lymphocyte trafficking and the microglial and neuronal responses to facial nerve axotomy. Neurosci Lett 2007;417:160-164.

Hoontrakoon R, Chu HW, Gardai SJ, Wenzel SE, McDonald P, Fadok VA, Henson PM, Bratton DL: Interleukin15 inhibits spontaneous apoptosis in human eosinophils via autocrine production of granulocyte macrophagecolony stimulating factor and nuclear factor-kappaB activation. Am J Respir Cell Mol Biol 2002;26:404-412.

36 Yeh WC, Shahinian A, Speiser D, Kraunus J, Billia F, Wakeham A, de la Pompa JL, Ferrick D, Hum B, Iscove N, Ohashi P, Rothe M, Goeddel DV, Mak TW: Early lethality, functional NF-kappaB activation, and increased sensitivity to TNF-induced cell death in TRAF2deficient mice. Immunity 1997;7:715725 .

37 Natoli G, Costanzo A, Guido F, Moretti F, Bernardo A, Burgio VL, Agresti C, Levrero $M$ : Nuclear factor kBindependent cytoprotective pathways originating at tumor necrosis factor receptor-associated factor 2. J Biol Chem 1998;273:31262-31272.

McDonald PP, Russo MP, Ferrini S, Cassatella MA: Interleukin-15 (IL-15) induces NF-kappaB activation and IL-8 production in human neutrophils. Blood 1998;92:4828-4835.

39 Abbott NJ, Patabendige AA, Dolman DE, Yusof SR, Begley DJ: Structure and function of the blood-brain barrier. Neurobiol Dis 2010;37:13-25.

40 Abbott NJ, Ronnback L, Hansson E: Astrocyte-endothelial interactions at the blood-brain barrier. Nat Rev Neurosci 2006; 7:41-53.

41 Minshall RD, Malik AB: Transport across the endothelium: regulation of endothelial permeability. Handb Exp Pharmacol 2006;176:107-144.

Pan W, Kastin AJ: Tumor necrosis factor and stroke: role of the blood-brain barrier. Prog Neurobiol 2007;83:363374.

43 Song L, Ge S, Pachter JS: Caveolin-1 regulates expression of junctionassociated proteins in brain microvascular endothelial cells. Blood 2007;109:15151523.

Amasheh M, Fromm A, Krug SM, Amasheh S, Andres S, Zeitz M, Fromm M, Schulzke JD: TNFalpha-induced and berberine-antagonized tight junction barrier impairment via tyrosine kinase, Akt and NFkappaB signaling. J Cell Sci 2010;123:4145-4155.
Mendez MG, Kojima S, Goldman RD: Vimentin induces changes in cell shape, motility, and adhesion during the epithelial to mesenchymal transition. FASEB J 2010;24:1838-1851.

$\checkmark 46$ Schoumacher M, Goldman RD, Louvard D, Vignjevic DM: Actin, microtubules, and vimentin intermediate filaments cooperate for elongation of invadopodia. J Cell Biol 2010;189:541-556.

$\$ 47$ Nishiyama R, Sakaguchi T, Kinugasa T, Gu X, MacDermott RP, Podolsky DK, Reinecker HC: Interleukin-2 receptor beta subunit-dependent and -independent regulation of intestinal epithelial tight junctions. J Biol Chem 2001;276:3557135580 .

Wang L, Lim EJ, Toborek M, Hennig B: The role of fatty acids and caveolin- 1 in tumor necrosis factor alpha-induced endothelial cell activation. Metabolism 2008;57:1328-1339.

49 Silwedel C, Forster C: Differential susceptibility of cerebral and cerebellar murine brain microvascular endothelia cells to loss of barrier properties in response to inflammatory stimuli. J Neuroimmunol 2006;179:37-45.

50 Yu C, Kastin AJ, Pan W: Cell-type specific response to hypoxia in relation to differential cytokine receptor expression. Abstract of the Society for Neurosci 2006;83.14.

Fasler-Kan E, Suenderhauf C, Barteneva N, Poller B, Gygax D, Huwyler J: Cytokine signaling in the human brain capillary endothelial cell line hCMEC/ D3. Brain Res 2010;1354:15-22.

Potokar M, Kreft M, Li L, Daniel AJ, Pangrsic T, Chowdhury HH, Pekny M, Zorec R: Cytoskeleton and vesicle mobility in astrocytes. Traffic 2007;8:12-20.

Haseloff RF, Krause E, Bigl M, Mikoteit K, Stanimirovic D, Blasig IE: Differential protein expression in brain capillary endothelial cells induced by hypoxia and posthypoxic reoxygenation. Proteomics 2006;6:1803-1809.

Deli MA, Descamps L, Dehouck MP, Cecchelli R, Joo F, Abraham CS, Torpier $\mathrm{G}$ : Exposure of tumor necrosis factoralpha to luminal membrane of bovine brain capillary endothelial cells cocultured with astrocytes induces a delayed increase of permeability and cytoplasmic stress fiber formation of actin. J Neurosci Res 1995;41:717-726. 